\title{
Emerging Adulthood, Regular Migration and Sexuality: Latin American immigrants in Madrid
}

\author{
Idade Adulta Emergente, Migração Regular e Sexualidade: imigrantes Latino- \\ Americanos em Madri
}

\author{
Itzel Eguiluz \\ Instituto Universitario de Investigación José Ortega y Gasset - España \\ im.eguiluz@gmail.com
}

\begin{abstract}
The main idea of this paper is to discuss the sexual and reproductive health of Latin American immigrants in Madrid, answering the question: Are they having different behaviours than in their origin countries and, if yes, which ones? The sample focuses on regular immigrants, men and women, that fit into the emerging adulthood category (18-29 years old) exploring through thirty-two in-depth interviews about their sexual believes and behaviours, especially during migration. Regular Latin American immigrant's sexuality in Europe has been rarely addressed by researchers. Even the known importance of irregular migration sexuality studies, because of the risks and vulnerability to which they are exposed, we should also ask ourselves about what is happening with those regular migrants that fit into the emerging adult category: those who are emigrating to pursue college or postgraduate courses, those who have been living in their parent's home until migration, and that in most cases are not married, and do not have children. Is their regular immigrant status leaving them aside from public health programs and researches because at first sight they doesn't imply a politic or economic issue for the receiving country? It doesn't mean that that migrants imply problems; it means that we need to leam how this group is sexually and reproductive behaving and what leads it to this point.
\end{abstract}

Keywords: Regular Migration; Latin America; Emerging Adulthood; Sexualities; Health

\section{Resumo}

A idéia principal deste artigo é discutir a saúde sexual e reprodutiva dos imigrantes latino-americanos em Madri, respondendo à pergunta: Eles estão tendo comportamentos diferentes do que em seus países de origem e, se sim, quais? A amostra incide sobre imigrantes regulares, homens e mulheres, que se encaixam na categoria adulta emergente (18-29 anos de idade). Os seus comportamentos e crenças sobre a sexualidade, especialmente durante a migração, foram explorados através de trinta e duas entrevistas em profundidade. A sexualidade dos imigrantes latinoamericanos na Europa tem sido pouco abordada pelos pesquisadores. Até mesmo a conhecida importância dos estudos de sexualidade da migração irregular, por causa dos riscos e vulnerabilidade a que estão expostos, também devemos nos perguntar sobre o que está acontecendo com esses migrantes regulares que se encaixam na categoria adulto emergente: os que estão a emigrar para perseguir faculdade ou cursos de pósgraduação, aqueles que têm vivido em casa de seus pais até a migração, e que na maioria dos casos não são casados, e não tem filhos. $\mathrm{O}$ seu estatuto de imigrante padrão, que os deixa de lado nos programas de saúde pública e nas pesquisas, ocorre porque à primeira vista eles não implicam uma política ou questão econômica para o país receptorber? Isso não significa que os migrantes impliquem problemas, mas significa que temos que compreender como é e o que define o comportamento sexual e reprodutivo do grupo.

Palavras-chave: Migração Regular; América Latina; Idade adulta; Sexualidades; Saúde 
The main idea of this paper is to discuss the sexual and reproductive health of Latin American immigrants in Madrid, briefly approaching three different questions: do they believe that there are differences about sexual and reproductive health issues between what they lived in their countries and Spain?; are they having different behaviors in Spain than in their origin countries and, if so, which ones?; and finally, what do they perceive about sexual health services and access in Spain?

Regular Latin American immigrant's sexuality in Europe has been rarely addressed by researchers, even with the known importance of irregular migration sexuality studies. And since there is risks and vulnerabilities to which migrants are exposed, we should ask ourselves about what is happening with those regular migrants that fit into the emerging adults category, those who are emigrating to pursue college or postgraduate courses, those who have been living in their parent's home until migration, and that, in most cases, are not married and don't have children.

First of all I want to make some methodological and theoretical considerations about the research from which this data come from. From a qualitative background the sample focuses on regular immigrants, women and men that fit into the emerging adulthood category. Thirty-two in depth interviews were made in Madrid, addressing sexual beliefs and behaviours through life, especially since they have left their countries. My research includes interviews with emerging adults from Argentina, Bolivia, Equator and Mexico. The exclusion criteria did not include sexual identity, but the final sample contains only one man who identifies himself as gay and only one woman who identifies herself as lesbian.

The interviews are part of my $\mathrm{PhD}$ research project and were analyzed using the
Ecological Development Theory (BRONFENBRENNER, 1979), emerging adulthood development stage (ARNETT, 2000), social construction of sexuality (WEEKS, 1998), and it is based on some premises of the grounded theory (GLASER and STRAUSS, 1967).

The research framework is based in the social ecological theory of development, which will be used as the basis for the analysis (along with the social construction and gender theories). The Ecological Theory is not being probed in this research; it is limited to be an organizing tool. The interview guide that we use tried to include all the systems in that theory (macro, micro, meso, exo, and chrono) (BRONFENBRENNER, 2006), and their probable relations through different issues, which will correspond to one or more systems. However, even though the theory did not define the study, it contributed to its design.

Grounded theory interprets data from the reality of the individual, and it is consistent with Berger and Luckmann's (1968) concept of the social construction of reality. Also, it is directly related with the concept of sexuality as a social construction. Weeks (1998) emphasizes, when talking about the social construction of sexuality, that "sexuality is not a given fact, it is a product of negotiation, struggle, and human actions" (p. 30).

Emerging adulthood was proposed in 2000 by Jeffrey Arnett (2000) to describe the group of people aged between $18-29$ years old. The theory basically includes 5 principles that can vary from country to country due to different cultural backgrounds: instability (work, love, education); exploration of identity; self-focus on personal goals; feeling in between (adultadolescent); high hopes for the future, positives ideas.

It has been argued that not all young people experience this life stage, since not 
everyone in the world has the chance to decide about their future, for example: in countries where girls and boys marry very young, (UNFPA, 2013) or when they face socioeconomic problems inside culture groups, adolescents may have to start their adult life early, which means working for a living - without chance for travelling or changing ideas of what they want to do with their lives - and having children at a very young age (UNFPA, 2013). This last issue has been changing in developed countries for the last decades, and also it's slowly happening in some Latin American countries. The Population Reference Bureau data shows that the average age of marriage in Latin American countries for men is around 25 and 22 for women, and in my sample few of them are married, some cohabitate but most of them are single (BUREAU, 2011).

The other two emerging adulthood behaviors that I want to address are leaving the parents home and travelling as a selffinding activity where sex is present. Even though in Latin America most people do not leave home before marriage and do not have the chance to travel (neither for a long time nor great distance), those who migrate, either to study a post grad, or to leave love behind or because they want to experience living in another country, do so.

Do they believe that there are differences concerning sexual and reproductive health issues between their countries and Spain? Are they having different behaviours in Spain than they had in their origin countries and, if so, which ones?

Migration has been associated with HIV risk, among other STI's (BARCLAY, 2005; CASTILLO-MANCILLA et al, 2012). But it is rarely studied in specific migrants groups. Also the comparative between sexual practices before and after migration are necessary for future results comparisons.

We can see a very clear pattern in the sample in which Mexicans and Argentineans do not demonstrate any real changes in their sexual practices, while most Bolivians and Ecuadorians do, although not necessarily in their selves. The first two groups speak freely about their sexuality, and also have more sexual partners in their histories.

Some men argue that Latin-American women, their spouses or relatives, change when they arrive in Spain. They say that in Spain they are sexually free, and their social behaviour is different, as going out at night alone with their girlfriends (Bolivian, 29 years old; Bolivian, 26 years old; Ecuadorian, 24 years old; Ecuadorian, 28 years old):

My girlfriend changed when we arrived here (Spain), she started to go out more at nights, and become freer. (Ecuadorian man, 24 years old).

Here women change, they like more tall and handsome men and therefore they change the way they dress, and their personality, they start to ask their selves about their sexual freedom. (Bolivian man, 29 years old).

All the Bolivian girls in the sample explained that 'machismo' was a reason to leave their origin country. (Bolivian, 28 years old; Bolivian, 27 years old; Bolivian, 28 years old; Bolivian, 28 years old). This 'machismo' is possibly related to the change men perceived in women's freedom:

In the couple relations that I had in Spain I had felt more free, I haven't felt that sense of being property of someone. Here there's a more horizontal way in couple relationships. (Bolivian woman, 28 years old).

In Spain there is more freedom than in Bolivia, in Bolivia you have to get married to live with your boyfriend. (Bolivian woman, 29 years old). 
Machismo was one of the reasons to leave Bolivia, there people is conservative and 'machista'. I think it is because religion and everything (sex) is a sin, and is seen as bad. (Bolivian woman, 28 years old).

Simple and straightforward relationships, along with a more direct way to sexual relationships, are common explanations for the differences the participants show between countries. In my research most of the emerging adults say they didn't changed their sexual practices after they migrated. All of them have had sex before in their countries, except for two, a man and a woman, who came to Spain when they were 17 years old.

Those who practice oral sex have done it before, except for one Bolivian woman who said that she learned of its existence after she arrived in Madrid. Coincidentally she is one of the very few participants that may not fit into the emerging adulthood category, since she has been cohabitating with kids, in some life periods (further analysis is needed).

The situation for the few that had practiced anal sex is similar. They had anal sex before in their countries, and keep practicing it with the same kind of couples. Most of them relate anal sex with someone they really care for:

I have had practice it with some girls, but is their decision. (Ecuadorian man, 30 years old).

We tried, but it was a bit painful, then we change positions, but we stop trying, we had a lot of confidence in each other. (Argentinean woman, 28 years old).

I haven't heard about it, neither oral nor anal sex, until I came to Spain. (Bolivian woman, 28 years old).

Migration may not change sexual practices per se in this sample, but it helps emerging adults to explore more freely ideas that they already had, with less social control, usually contrasting the ideas and values they've acquired at home with those that they want to live.

A public health issue that should be addressed is the lack of knowledge of dental dams or condoms for either oral or anal sex. That is an issue not only after they migrate to Spain but also in their origin countries. Sexual education should focus in preventing HIV/aids in these sexual practices. Except for one participant, no one in the sample knew about the existence of dental dams as an oral sex protection, although some participants mentioned condoms. The only one that knew about oral dams, a Mexican woman, worked in a sex shop.

Finally, what do they perceive about sexual and reproductive health services and

access in Spain? It is important to mention that migration is related to sexual health risks because of the lack of health services access. In Spain, as a student, you are obliged to buy medical insurance in order to obtain a student visa. But sometimes the insurance does not cover everyday medical needs. The insurance could be, for example, for emergencies, medical recognition, only for certain illnesses, among others. Recently the Spanish government changed the public health legislation; now immigrants in Spain only have access to public health insurances when they are working.

In regard to health access, immigrants in this sample argue that they prefer to go to health services in their countries. Different reasons are discussed as a factor to postpone medical check-ups or for waiting until the next travel to their country, as such: lack of trust, the felling of being badly attended or different cultural issues. The self-identified gay man says that he prefers to go to the doctor in his country because in Spain they didn't gave him an explanation of the HIV test results: 
It is really difficult to get a HIV test, I had a private insurance and the doctor, after a lot of paperwork, sends me to the laboratory, and then no one has time to explain me the results. The services are really bad, I prefer the Bolivian specialists. (Bolivian man, 27 years old).

Women stop making preventive check-ups for breast cancer or HPV, they argue for lack of time; that they do not like medical professional's way of working in Spain; and ignorance of the way their own insurance works. This is an important public health issue, due to the growing prevalence of breast and cervical cancer (JEMAL, 2011):

My insurance is only for emergencies, because of that I have to postpone my PAP test. Is expensive to pay for it now. (Bolivian woman, 29 years old).

I went during my pregnancy, but I didn't like the IUD idea, I prefer that my mom sends me injectable contraceptives from my country. (Ecuadorian woman, 27 years old).

I prefer to go [to the doctor] in Argentina, when I plan my vacations I also plan the visits to the gynecologist. I like better the attention there. (Argentinean woman, 29 years old).

Emerging adulthood is evolving, even though literature still focuses those emerging adults that have as goal marriage and kids in their late 20 `s. Thus, it is necessary to make a shift and work with the theory with other cultural groups, as regular migrants, that may have other life goals, at least in the near future. It is also relevant to focus on sexuality and migration concurrence where education, promotion, public health access, and social issues are present.

Finally, most of the sexual studies that have been done address vaginal sex as if there is no other kind of sexual practices; as if the only existing sexual practices were heteronormatives ones. The future question to address in this research would be: If literature is discussing about a Global Youth Culture, is there also a Global Youth Sexual culture? (BRONFENBRENNER, 2005). Also, exist the possibility for the participants to create a hybrid identity (HERMANS, 1998), as part of a globalized society?

\section{References}

BRONFENBRENNER, Urie. The ecology of Human Development. Cambridge: Harvard University Press, 1979.

ARNETT, Jeffrey Jensen. Emerging adulthood: A theory of development from the late teens through the tweenties. American Psychologist, v. 55, p. 469-480, 2000.

WEEKS, Jeffry. Sexualidad. México: Paidos, 1998.

GLASER, Barney; STRAUSS, Anselm. The Discovery of Grounded Theory. Chicago: Aldine, 1967.

BRONFENBRENNER, Urie; MORRIS, PAmela. The Bioecological Model of Human Development. In: DAMON, William; LERNER, Damon (Eds). Handbook of Child Psychology, Theoretical Models of Human Development. New Jersey: Wiley, 2006, p. $793-828$.

BERGER, Peter; LUCKMANN, Thomas. La construcción social de la realidad. Argentina: Amorrortu, 1968.

UNFPA. Motherhood in Childhood, en State of World Population. New York: UNFPA, 2013.

BUREAU, Population Reference. America - 
Latin America \& Caribbean Highlights. 2011.

BARCLAY, Elisa. Mexican Migrant Communities May Be on Verge of HIV/AIDS Epidemic. 2005. Disponible en: $<$ http://www.prb.org/Articles/2005/Mexican MigrantCommunitiesMayBeonVergeofHIVAI DS Epidemic.aspx.>. Acesso: 10/07/2008

BOERMA, J Ties; WEIR, Sharon Integrating Demographic and Epidemiological Approaches to Research on HIV/AIDS: The Proximate-Determinants Framework. Journal of Infectious Diseases, v. 191, p. 61 $-67,2005$.

CASTILLO-MANCILLA, Jose; ALLSHOUSE, Amanda; COLLINS, Caitilin (et al). Differences in sexual risk behavior and HIV/AIDS risk factors among foreignborn and US-born Hispanic women. Journal of immigrant and minority health / Center for Minority Public Health, v. 14, n. 1, p. 89-99, 2012.

JEMAL, Ahmedin; BRAY, Freddie; CENTER, Melissa; FERLAY, Jacques; WARD, Elizabeth; FORMAN, David. Global cancer statistics. CA: A Cancer Journal for Clinicians, v. 61, n. 2, p. 69-90, 2011.

HERMANS, Hubert; KEMPEN, Harry. Moving cultures: The perilous problems of cultural dichotomies in a globalizing society. American Psychologist, v. 53, p. 1111-1120, 1998. 